\title{
Impact of Earnings Smoothness on Stock Prices, Stock Returns and Future Earnings Changes - the Polish Experience
}

\author{
Jacek Welc
}

\section{Introduction}

Stock prices are formed by investors' expectations about future corporate earnings and investment risks, which are in turn influenced by historical earnings patterns. Because earnings forecasting is burdened by substantial inaccuracy, investors tend to appreciate companies with high earnings smoothness (which is a proxy for predictability of future earnings) and tend to avoid companies with considerable earnings instability. This suggests that companies with smooth past earnings are quoted with valuation premiums while stocks with erratic earnings are priced with valuation discounts. However, the empirical issue is whether these premiums and discounts are justified on the ground of the actual investment risks and future earnings changes.

Valuation premiums observed in market prices of stocks with relatively smooth historical earnings are legitimate only if such past earnings smoothness translates into either relatively low future investment risk or relatively fast future earnings growth (or both), as compared to other stocks. In the absence of the expected relationships among past earnings smoothness and future investment risks and / or future earnings growth, the valuation premiums for smooth historical earnings imply overvaluation. If this is the case, than portfolios of stocks with relatively smooth past earnings should bring sub-par future stock returns (due to overvaluation) while portfolios of stocks with more erratic historical earnings should generate above-average stock returns.

In this paper we explored the impact of historical earnings smoothness on relative stock prices, stock returns, investment risks and next-year reported earnings of companies listed on the Warsaw Stock Exchange.

Dr. Jacek Welc - Assistant Professor; Wroclaw University of Economics, Nowowiejska 3, 58-500 Jelenia Gora, Poland, <jacek.welc@ue.wroc.pl>. 
First, we tested whether there exists positive empirical relationship between past earnings smoothness and relative stock prices (as measured by price-to-sales multiples). Then, after confirming the presence of such relationship, we checked whether and how the scope of past earnings smoothness translates into future stock returns and realized investment risks (as measured by standard measures of stock return variability). If past earnings smoothness is considered a proxy for the investment risk, then stocks with relatively smooth / erratic patterns of historical earnings should be associated with relatively low / high Beta coefficients and return variability. Finally, we explored the statistical properties of nextyear reported earnings within portfolios of stocks formed on the ground of past earnings smoothness. If observed valuation premiums of stocks with smooth past earnings reflect investors' expectations of above-average future earnings growth (instead of below-average investment risk), then stocks with smooth patterns of historical earnings should provide relatively fast next-year earnings growth. If, however, stocks with smooth past earnings offer neither relatively low future investment risk nor relatively fast future earnings growth, then their observed valuation premiums imply overvaluation. In such a case the valuation premium is undeserved and reflects the investors' over-extrapolation of past earnings patterns (which results in sub-par stock returns).

The remainder of the paper is organized as follows. In the next two sections we discuss the theoretical foundations and relevant literature. Next the data and methodology used in the study are described. Then the section that presents the empirical findings follows. The paper closes with concluding comments.

\section{Theoretical foundations}

The fundamental model of valuing stocks is based on discounted cash flows. However, in the long-run the sum of earnings should not differ significantly from the sum of cash flows. Thus, for simplicity's sake cash flows can be substituted for earnings. Let's assume the case of constant growth, where the fundamental stock value is derived from the following formula:

$$
P_{t}=\frac{E_{t}(1+g)}{r-g},
$$

where $P_{t}=\begin{aligned} & \text { fundamental value of a common stock at the end of } \\ & t \text {-th period, }\end{aligned}$ 


$$
\begin{array}{ll}
E_{t} & =\text { corporate earnings per share in } t \text {-th period, } \\
r & =\text { discount rate (cost of capital) } \\
g & =\text { expected growth rate of earnings, }
\end{array}
$$

According to formula (1), the stock value is a derivative of current earnings, expected earnings growth and cost of capital. Valuation multiples, which are popular valuation tools, also have their theoretical foundations in the same model. Price-to-earnings multiple, which is the most frequently used by analysts (Fernandez 2002), can be derived from formula (1) by dividing its left side by earnings per share (Jones 1998). Analogous transformations made for the other multiples enable obtaining their theoretical foundations. This is presented in Table 1.

The higher the expected earnings growth and the lower the discount rate, the higher the theoretical values of multiples. However, due to the generally high inaccuracy of earnings forecasts (O'Brien 1988; Brown 1996; Dreman 1998; Malkiel 2007; Rothovius 2008), investors tend to appreciate companies with relatively smooth past earnings. Therefore, relatively high past earnings smoothness has positive impact on stock prices and relatively low past earnings smoothness has depressing impact on stock prices. This is because a market belief in high/low predictability of future earnings (which is in turn negatively related to variability of past earnings) implies low/high perceived investment risk and decreases/increases a required cost of capital. Because cost of capital is negatively related to theoretical values of valuation multiples, the stocks with relatively high past earnings smoothness tend to be priced with above-average multiples.

\section{Tab. 1. Theoretical foundations of valuation multiples}

\begin{tabular}{|c|c|c|}
\hline Price-to-earnings multiple & Price-to-book-value multiple & Price-to-sales multiple \\
\hline$P_{t} / E_{t}=\frac{1+g}{r-g}$, where: & $P_{t} / B V_{t}=\frac{E_{t}}{B V_{t}} \frac{1+g}{r-g}$, where: & $P_{t} / S_{t}=\frac{E_{t}}{S_{t}} \frac{1+g}{r-g}$, where: \\
$P_{t} / E_{t}$ - price-to-earnings & $P_{t} / B V_{t}$ - price-to-book-value & $P_{t} / S_{t}$ - price-to-sales multiple \\
multiple at the end of period $t$, & at the end of period $t$, \\
multiple at the end of period $t$, & $B V_{t}$ - shareholders' equity per & $S_{t}$ - net sales per share in \\
remaining notations as in & share at the end of period $t$, & period $t$, \\
formula (1). & remaining notations as in formula \\
& (1). & $\begin{array}{c}\text { remaining notations as in } \\
\text { formula (1). }\end{array}$ \\
\hline
\end{tabular}

Source: Author's work. 
The above discussion touches the impact of the perceived (and not the actual) predictability of earnings on stock prices. The important empirical question is therefore: what factors determine the extent to which investors perceive future earnings as predictable? Perhaps, as suggested by the "anchoring effect" theory, there exists a positive relationship between past earnings smoothness and expected predictability of future earnings. If smooth past earnings are deemed as a "promise" of highly predictable future earnings, then historical earnings smoothness should be positively correlated with observed valuation multiples.

The related empirical issue is whether treating historical earnings smoothness as the proxy for the predictability of future earnings is justified. If past earnings are not strongly related to future earnings, then valuing smooth past earnings with premiums and erratic past earnings with discounts may result in stock mispricing. Specifically, if earnings smoothness is mean-reverting, then valuation premiums stemming from smooth past earnings result in stock overvaluation while valuation discounts stemming from noisy past earnings result in stock undervaluation. Therefore, apart from testing the presence of the statistical relationships between past earnings smoothness and relative stock prices, we also test the impact of past earnings smoothness on future stock returns and future variability of these returns. Given that stock prices are to a large extent driven by changes in earnings, we also examine the relationships between past five-year earnings smoothness and next-year earnings.

\section{Literature review}

\subsection{Past earnings smoothness and stock values}

In one of the first papers related to income smoothness, Hepworth (1953) suggested that earnings stability increases shareholders' confidence in company's prospects. This is so because smooth earnings may reflect relatively low perceived information uncertainty about the company's future economic results (Jiang et al. 2005). Gordon (1964) suggests that relatively smooth earnings entail relatively high dividend rate. Many empirical studies confirmed that smooth past earnings are viewed favourably by the markets, and firms with smoother income series are perceived as being less risky (Wang and Williams 1994). Others found that institutional investors and analysts tend to prefer companies with smooth earnings (Badrinath et al. 1989; Previts et al. 1994; Carlson and Bathala 1997). 
If stable income patterns are associated with low investment risk, than companies with smooth earnings should be associated with low cost of equity capital (Easley and O'Hara 2004). Indeed, research studies confirm that earnings variability and cost of equity capital are positively related (Beaver et al. 1970; Rosenberg and McKibben 1973; Lev and Kunitsky 1974; Bowman 1979; Gebhardt et al. 1999; Gode and Mohanram 2001; Wang and Williams 1994; Verdi 2006; Chen 2009; Markarian and Gillde-Albornoz 2010). Other researchers suggested that relatively smooth earnings might be also associated with relatively low cost of debt because lower volatility in earnings lowers the assessment of the possibility of a firm's bankruptcy (Trueman and Titman 1988). Others suggested that smoother income reduces the probability of breaking debt covenants (Beattie et al. 1994). The empirical studies corroborate that smooth earnings entail low observed cost of debt ( $\mathrm{Gu}$ and Zhao 2006; Li and Richie 2009). Others found that increased earnings smoothness reduces the likelihood of a downgrade of corporate debt ratings (Jung et al. 2012).

If income smoothness reduces the cost of capital, then stocks with smooth earnings should be associated with relatively high valuation multiples and stocks with erratic earnings should be associated with relatively low valuation multiples. Indeed, many studies confirm the existence of a negative statistical relationship between variability of earnings and stock values (Barth et al. 1999; Hunt et al. 2000; Francis et al. 2004; Rountree et al. 2008; Allayannis and Simko 2009; Chen 2009). Moreover, this negative relationship remains after controlling for cash flow volatility, which confirms that smoothness of accrual-based numbers (and not only cash flows) matters for stock prices (Barnes 2001; Mäkelä 2012).

\subsection{Evidence of earnings smoothing behaviour}

Smooth earnings can be "naturally-smooth" (resulting from e.g. low operating leverage) or "artificially-smooth" (i.e. smoothed by earnings management techniques). The positive relationship between stock prices and earnings smoothness may motivate managers to "cook the books" to report allegedly stable income. Indeed, researchers found that majority of CFOs prefer smooth earnings (Graham et al. 2005; Fudenberg and Tirole 1995; Suda and Hanaeda 2008) and empirical studies supported the notion that managers tend to engage in accounting income smoothing (Dascher and Malcolm 1970; Barefield and Comiskey 1972; Beidleman 1973; Barnea et al. 1975; Ronen and Sadan 1981). Because of this, a disagreement exists as to whether smoothness is a desirable property of 
Welc, J.: Impact of Earnings Smoothness on Stock Prices, Stock Returns and Future Earnings Changes - the Polish Experience.

earnings. Chaney and Lewis (1995) suggest that smoothing is used by "high quality" firms to signal their type. However, Bhattacharya et al. (2003) contend that smoothing leads to greater earnings "opacity" and Myers et al. (2007) offer evidence that firms use smoothing as a tool to maintain artificially long strings of increasing earnings.

\subsection{Past earnings smoothness and stock returns}

Research studies exploring the relationships between earnings smoothness and stock returns produced mixed results. Some researchers found that companies with smooth profits provide above-average longterm returns (Billings 1999; Michelson et al. 2000). However, McInnis (2010) found no statistically significant relationship between earnings smoothness and stock returns and some other studies indicated that relatively smooth earnings entail below-average stock returns (Booth 1996; Singer 2007; Aflatooni and Nikbakht 2010). This inconsistency of findings may result from varying sources of earnings smoothness in different periods and different countries. If earnings smoothness stems from the natural sources, then stocks with smooth incomes should be more correctly priced. However, if smooth profits result from deliberate earnings manipulations, then information asymmetry occurs and market efficiency deteriorates.

Although not relating directly to income smoothness, Lakonishok et al. (1994) found that investors in growth stocks tend to rely too heavily on past earnings growth when forecasting the future. If investors tend to over-extrapolate past growth, then they may also over-extrapolate past risk metrics (such as earnings stability). Others found that analyst and institutional investors following is positively associated with the natural smoothness in income, but negatively associated with the managed smoothness (Dey 2004). It suggests that the extent to which stock markets efficiently price the sources of past earnings smoothness is positively related to the share of institutional investors in a market trade. This, in turn, may influence the relative returns from investing in stocks with smooth patterns of earnings.

Some authors suggested that earnings smoothness is relatively credible in the U.S. because strong investors' protection limits the ability of insiders to extract private benefits from "cooking the books". If this is the case, then the weight of the natural smoothness (as opposed to the artificial smoothness) is high in the US, while it may be lower in countries with poorer investors' protection. Amiram and Owens (2010) 
confirm that smooth earnings are negatively associated with the cost of capital in the U.S. while positively associated with the cost of capital in countries with weaker investors' protection. It means that smooth earnings are interpreted as reducing the risk in the U.S. while boosting the risk in other countries. Other researchers documented that managers in countries with a weak investors' protection tend to smooth reported earnings to mask firms' true performance in an attempt to shield their private control benefits (Leuz et al. 2003).

\subsection{Past earnings smoothness and future earnings}

Researchers found that earnings smoothness is associated with a higher accuracy of analysts' earnings forecasts (He et al. 2010) and earnings volatility relates negatively to earnings persistence (Dichev and Tang 2009; Takasu and Nakano 2012). It means that smooth profits reduce risk (by allowing to forming more precise predictions). However, in those cases where earnings smoothness stems from the accounting manipulations (as documented by Myers et al. 2007), the following negative earnings surprises (which may be deep if past income smoothing entailed earnings overstatements) may be more surprising than earnings surprises from non-manipulating firms. If companies artificially smooth growing earnings, then valuation premiums entail overvaluation. This is confirmed by empirical studies, according to which companies with smoothly growing earnings are priced at premium, and significant downward adjustment occurs when that growth ends (Nelson et al. 2002; Graham et al. 2005).

As Goel and Thakor (2000) note, artificial earnings smoothing reduces measured volatility when shocks to earnings in successive periods tend to offset each other. However, if earnings shocks are positively serially correlated, then the artificial smoothing of past earnings may increase variability of future earnings. If a company smoothes earnings which are showing rising trends and later it faces a negative earnings shock (which the company offsets by artificially overstating earnings), the following negative shock (occurring if shocks tend to be positively correlated) brings about deeper negative earnings surprise as compared to non-smoothing scenario. This seems to be corroborated by research, according to which relatively low stock returns of "growth stocks" can be explained by large and asymmetric responses to negative earnings surprises and although growth stocks underperform on average, they systematically outperform in periods when they report few negative earnings surprises (Skinner and Sloan 1999). 
Welc, J.: Impact of Earnings Smoothness on Stock Prices, Stock Returns and Future Earnings Changes - the Polish Experience.

\section{Data and research method}

In our research we used the data from years 1998 - 2013. Although the Warsaw Stock Exchange functions since 1991, we omitted all periods before 1998 due to the small number of listed companies as well as due to the relatively high inflation in Poland at that time.

Our research was conducted in three steps. First, we examined the empirical relationships between past earnings smoothness and relative stock prices. Then we compared the long-term nominal returns and the variability of returns of stock portfolios formed on the basis of past earnings smoothness. Finally, we compared the averaged next-year earnings growth of those stock portfolios and we estimated the scope and direction of the bias of one-year ahead net earnings predictions extrapolated from the linear trends of past five-year earnings.

\subsection{Relationship between past earnings smoothness and relative stock prices}

In examining the relationships between past earnings smoothness and stock prices we applied the concept of a Granger causality (Charemza and Deadman 1997). We applied the following modification of the traditional Granger causality procedure:

1. for years 2003 - 2012 we estimated ten regressions of price-to-sales multiples, at the end of February each year, against the set of explanatory variables composed of the accounting ratios which were found to have statistically significant relationships with the price-tosales multiple,

2. for each of these regressions we computed the residuals, i.e. the differences between the actual values of the valuation multiples and their fundamental values obtained from the respective regression (denoted as $V M_{e}-V M_{t}$ ),

3. for each of the ten regressions we sorted all the observations in order of decreasing values of the measure of past earnings smoothness and then we divided all sorted observations (separately for each regression) into five portfolios so that the first portfolio covered $20 \%$ of stocks with the highest smoothness of past earnings and the fifth portfolio covered $20 \%$ of stocks with the lowest smoothness of past earnings, 
4. for each of the five portfolios we pooled the respective observations from all ten regressions and we computed median residual $\left(V M_{e}-V M_{t}\right)$ within each portfolio,

5. we tested the statistical significance of differences between medians of residuals obtained for five portfolios by means of the Wilcoxon Rank-Sum test.

In order to apply the concept of Granger causality in estimating the relationships between past earnings smoothness and stock prices we used price-to-sales multiple. This choice stems from the fact that its empirical distribution is usually more symmetric than in the case of other multiples (Welc 2011). Moreover, sales revenues are almost always positive (except for small number of companies), which enables estimations based on larger and more representative samples (including companies with negative earnings and negative shareholders' equity).

As the measure of past earnings smoothness we applied the coefficient of determination of a linear trend function, in which past five-year annual net earnings constitute the dependent variable and a trend variable (i.e. numbers of years) constitutes the only explanatory variable. The number of years (five), on the basis of which we estimated the trend functions, was chosen arbitrarily. We believe that shorter periods would heavily increase the risk of obtaining spurious regressions while longer periods would significantly limit the time-span of the analysis.

Although we used the data from 1998 - 2012 periods, we could estimate the regressions for only ten years. This is due to the loss of five years of data (1998 - 2002) when estimating smoothness measure for the first regression. As a result, the first regression was estimated for the end of February 2003 and the measure of earnings smoothness for this regression was based on earnings from 1998 - 2002 sub-period. The last regression was estimated for the end of February 2012 and the measure of earnings smoothness for this regression was based on earnings from 2007 - 2011 sub-period.

The regressions were estimated for the end of February in order to allow for the passage of time between the end of the year and the day when all the quarterly reports for that year are publicly available. In the research we included all companies that we obtained all the necessary data for, excluding foreign companies and financial institutions (due to the accounting differences). To reduce the distorting effect of the outliers we estimated each regression on the basis of the whole initial sample, 
reduced by exclusion of observations identified as the outliers. To detect the outliers we applied the method based on the analysis of the significance of regression coefficients obtained for dummy variables constructed for potential outliers (Evans 2003). We started with the regression based on all available observations. Then we found the residual with the largest absolute value and we constructed a dummy variable with the value of unity in the case of that residual and zero otherwise. This auxiliary variable was added to the regression and the coefficients were re-estimated. If such a dummy variable turned out to be statistically significant we assumed that this observation is an outlier and we removed it from the sample. Next, we re-estimated the regression and we again found the residual with the largest absolute value, for which we repeatedly constructed a dummy variable. This dummy variable was added to the regression and the coefficients were again re-estimated. The procedure was repeated until the dummy variable for another potential outlier turned out to be statistically insignificant.

In the regressions the set of potential explanatory variables covered commonly used accounting ratios (including profitability, liquidity, indebtedness and turnover). In selecting the final set of the explanatory variables we applied the procedure of a stepwise regression described in the work of Nilsson and Nilsson (1994). At every stage of the estimation we evaluated the statistical significance of variables at $5 \%$ significance level as well as the general regression significance. In order to limit the impact of potential heteroscedasticity of residuals on the regression results we applied the weighted least squares estimation procedure. The weights for individual observations were computed as inverses of absolute values of the residuals obtained from the regression estimated by ordinary least squares. All the regressions were estimated with logarithmic functional form (based on logged values of all variables).

The estimated regressions enabled calculations of the "regressionbased multiples". These are the fitted multiples of individual companies given their actual financial results. However, usually the actual multiples deviate from their regression-based values. This is the result of omitting many value-drivers, including past earnings smoothness. If past earnings smoothness significantly influences stock prices, then our proxy for smoothness (coefficient of determination of past five-year linear trend of earnings) should be positively correlated with the regression residuals. To test this we evaluated the statistical significance of differences among median residuals obtained for five portfolios, by means of the Wilcoxon Rank-Sum test. 


\subsection{Relationship between past earnings smoothness and future stock returns}

In the second step of our research we compared the long-term nominal returns (and variability of those returns) of the stock portfolios formed on the basis of past earnings smoothness. This was aimed at verifying the extent to which past earnings smoothness influences profitability of stock investments. We treated all five portfolios as the alternative investment strategies. Thus, we assumed that buying stocks from the first portfolio is equivalent to the strategy of investing in $20 \%$ of companies with the highest earnings smoothness and buying stocks from the fifth portfolio is equivalent to investing in $20 \%$ of companies with the lowest earnings smoothness. Within all portfolios the equal weights for all stocks were applied.

We assumed the annual rebalancing (at the end of February) of all portfolios. For all portfolios the annual nominal returns (for the periods between the end of February of a given year and the end of February of the next year) were computed. Next, the geometric mean of nominal returns in a ten-year period between the end of February 2003 and the end of February 2013 were calculated. The geometric mean was chosen because it represents the constant return an investor must earn every year to arrive at the same final value that would be produced by a series of variable returns (Cornell 1999). The dividends and transaction costs were disregarded, due to the lack of any reliable database regarding them.

\subsection{Relationship between past earnings smoothness and next-year earnings}

In the final step we estimated the relationships between past earnings smoothness and next-year earnings. First, we measured the bias of the one-year ahead earnings predictions derived from the linear trends of past five-year earnings. This was aimed at testing the extent to which past earnings smoothness affects the accuracy of earnings extrapolations. From every five-year trend of earnings we computed the extrapolative forecast of earnings for the following year, and then for each such prediction we calculated forecast error with the following formula (the absolute value was applied in denominator due to frequently reported negative earnings): 


$$
P F E_{t}=\frac{F N E_{t}-A N E_{t}}{\left|A N E_{t}\right|} \times 100,
$$

where $P F E_{t}=$ percentage forecast error in $t$-th period,

$$
\begin{aligned}
F N E_{t}= & \text { annual net earnings extrapolated for } t \text {-th period } \\
& \text { from the linear trend of past five-year earnings, } \\
A N E_{t}= & \text { annual net earnings reported for } t \text {-th period. }
\end{aligned}
$$

We compared median percentage forecast errors between five portfolios. We also compared the median next-year growth of earnings within these portfolios. This was aimed at evaluating the scope to which past earnings smoothness translates into relative growth of next-year earnings. For every observation we computed the earnings growth in the following (i.e. sixth) year with the following formula:

$$
N E G_{t}=\frac{A N E_{t}-A N E_{t-1}}{\left|A N E_{t-1}\right|} \times 100,
$$

where $N E G_{t}=$ net earnings growth in $t$-th period.

\section{Empirical findings}

\subsection{Relationship between past earnings smoothness and price-to- sales multiples}

Table 2 presents the results of regressing P/S multiples against the historical (previous year) accounting ratios. As might be seen, all ten regressions are statistically significant below $1 \%$ significance level. Assets turnover and indebtedness are significant in all regressions (with negative signs), and operating profitability is significant in all but one regression (with a positive sign, except for February 2003). The only other variable, which appears significant, is sales growth, but it occurs only in regression for February 2006. 
Tab. 2. The logarithmic regressions of $P / S$ (price-to-sales) multiples
against the accounting ratios

\begin{tabular}{|c|c|c|c|c|}
\hline \multirow{3}{*}{$\begin{array}{l}\text { Regression } \\
\text { estimated } \\
\text { for } \\
\text { the end of } \\
\text { February of: }\end{array}$} & \multirow{3}{*}{$\begin{array}{c}\text { Dependent variable: } \\
\text { P/S multiple } \\
\begin{array}{c}\text { Explanatory variables } \\
\text { (signs of parameters in } \\
\text { brackets)* }\end{array}\end{array}$} & \multicolumn{3}{|c|}{ Additional statistics } \\
\hline & & \multirow[b]{2}{*}{$\begin{array}{c}\text { Sample } 1 \text { / } \\
\text { Sample 2** }\end{array}$} & \multirow[b]{2}{*}{$\begin{array}{c}\text { Adjusted } \\
\text { R-squared }\end{array}$} & \multirow[b]{2}{*}{$\underset{\text { statistic } * * * *}{\mathbf{F}}$} \\
\hline & & & & \\
\hline 2003 & $M(-), T(-), L(-)$ & $102 / 141$ & 0.516 & $36.93(0.000)$ \\
\hline 2004 & $T(-), L(-)$ & $86 / 130$ & 0.445 & $35.07(0.000)$ \\
\hline 2005 & $M(+), T(-), L(-)$ & $91 / 138$ & 0.623 & $50.52(0.000)$ \\
\hline 2006 & $M(+), T(-), L(-), S G(+)$ & $147 / 182$ & 0.513 & $39.43(0.000)$ \\
\hline 2007 & $M(+), T(-), L(-)$ & $132 / 179$ & 0.510 & $46.47(0.000)$ \\
\hline 2008 & $M(+), T(-), L(-)$ & $242 / 264$ & 0.461 & $69.73(0.000)$ \\
\hline 2009 & $M(+), T(-), L(-)$ & $231 / 300$ & 0.513 & $81.91(0.000)$ \\
\hline 2010 & $M(+), T(-), L(-)$ & $181 / 202$ & 0.528 & $68.21(0.000)$ \\
\hline 2011 & $M(+), T(-), L(-)$ & $258 / 317$ & 0.655 & $16.40(0.000)$ \\
\hline 2012 & $M(+), T(-), L(-)$ & $302 / 338$ & 0.489 & $97.17(0.000)$ \\
\hline
\end{tabular}

Source: Money.pl; Notoria Serwis; author's calculations.

Note: * notation of the explanatory variables: M (Margin) $=$ operating profit in the last year / net sales in the last year. $\mathrm{T}$ (Turnover) $=$ net sales in the last year / total assets at the end of the last year. L (Leverage) $=$ total liabilities and provisions at the end of the last year / total assets at the end of the last year. SG (Sales growth) $=$ net sales in the last year / net sales in the next-to-last year; ** Sample 1 consists of all the observations (companies) used in regression estimation, after detecting and excluding the outliers; Sample 2 consists of all the observations (companies) for which the fitted values of P/S multiple were computed (including the outliers removed from Sample 1); *** statistical significance of $F$ statistics in brackets

Table 3 presents median residuals from all ten regressions as well as median coefficients of determination of past earnings trends. The data confirm that there exists positive statistical relationship between past earnings smoothness and relative stock prices. The averaged residuals rise 
monotonically with the growing smoothness of past earnings. Table 4 contains the absolute values of the Wilcoxon Rank-Sum test statistics for the differences between the median regression residuals. As can be seen, the differences between the medians for the adjacent portfolios are statistically insignificant at $5 \%$ significance level. However, all the differences between the medians for non-adjacent portfolios are statistically significant.

To sum up, our analysis seems to corroborate that stocks with relatively smooth past earnings tend to be priced with valuation premiums, after controlling for other accounting fundamentals, while stocks with relatively erratic past earnings tend to be priced with valuation discounts. Thus, it suggests that on the Polish stock market the investors tend to reward companies with the above-average smoothness of past earnings by valuing them relatively high and to penalize companies with the below-average earnings smoothness by valuing them relatively low.

\section{Tab. 3. The median residuals from the logarithmic regressions of $P / S$ multiples and the median coefficients of determination of past five-year earnings trends}

\begin{tabular}{|c|c|c|c|c|c|}
\hline Medians of: & $\begin{array}{c}\text { Portfolio } \\
\mathbf{1}^{*}\end{array}$ & $\begin{array}{c}\text { Portfolio } \\
\mathbf{2}\end{array}$ & $\begin{array}{c}\text { Portfolio } \\
\mathbf{3}\end{array}$ & $\begin{array}{c}\text { Portfolio } \\
\mathbf{4}\end{array}$ & $\begin{array}{c}\text { Portfolio } \\
\mathbf{5}^{* *}\end{array}$ \\
\hline $\begin{array}{c}\text { Regression } \\
\text { residuals }\end{array}$ & 0.029 & 0.009 & 0.007 & -0.005 & -0.016 \\
\hline $\begin{array}{c}\text { Earnings } \\
\text { smoothness } * * *\end{array}$ & 0.890 & 0.628 & 0.410 & 0.185 & 0.019 \\
\hline
\end{tabular}

Source: Money.pl; Notoria Serwis; author's calculations.

Note: $* 20 \%$ of companies with the largest coefficients of determination of past fiveyear linear trends of earnings; ** $20 \%$ of companies with the smallest coefficients of determination of past five-year linear trends of earnings; *** medians of coefficients of determination of past five-year linear trends of earnings. 
Tab. 4. The absolute values of the Wilcoxon Rank-Sum test statistics* for the differences between median regression residuals obtained for the five portfolios

\begin{tabular}{|l|c|c|c|c|c|}
\hline & Portfolio & Portfolio & Portfolio & Portfolio & Portfolio \\
\hline Portfolio 1 & - & 1.90 & 2.63 & 4.07 & 5.59 \\
\hline Portfolio 2 & & - & 0.75 & 2.32 & 3.78 \\
\hline Portfolio 3 & & & - & 1.37 & 2.75 \\
\hline Portfolio 4 & & & & - & 1.33 \\
\hline Portfolio 5 & & & & & - \\
\hline
\end{tabular}

Source: Money.pl; Notoria Serwis; author's calculations.

Note: * value above 1.96 means that the difference between the two medians is statistically significant at $5 \%$ significance level

\subsection{Relationship between past earnings smoothness and future stock returns}

Table 5 presents the risk and return statistics obtained for the investigated five portfolios.

The data indicate that the stocks with smooth past earnings bring lower long-term returns than the stocks with more erratic earnings. In the investigated ten-year period the average returns of the portfolios of stocks with most noisy earnings (Portfolio 5 and Portfolio 4) exceeded the average returns of the portfolios with the smoothest earnings (Portfolio 1 and Portfolio 2) by approximately $4-5$ percentage points.

These excess returns of portfolios 5 and 4 may reflect the premiums related to the perceived high investment risk, associated with the expected low predictability of earnings. Investors tend to price smooth past earnings with relatively high valuation multiples and erratic past earnings with relatively low multiples, which is consistent with expecting relatively high returns from stocks with seemingly unpredictable earnings. The relatively low equity-risk premium of stocks with smooth past earnings and relatively high equity-risk premium of stocks with relatively noisy past earnings seem to be materialized in their realized returns. However, such a positive risk-return relationship is not confirmed by the standard measures of the realised risk. The Beta coefficients do not show any discernible differences between the investigated portfolios. The 
Welc, J.: Impact of Earnings Smoothness on Stock Prices, Stock Returns and Future Earnings Changes - the Polish Experience.

standard deviations of returns are also rather comparable. The only visible differences appear for the coefficients of variation of returns, which however are somewhat smaller for the portfolios with the most erratic past earnings, as compared to the portfolios with smooth past earnings.

Tab. 5. The risk and returns statistics for the five alternative
portfolios

\begin{tabular}{|c|c|c|c|c|c|}
\hline & $\begin{array}{c}\text { Portfolio } \\
\mathbf{1} \\
\text { (stocks } \\
\text { with the } \\
\text { smoothes } \\
\text { t past } \\
\text { earnings) }\end{array}$ & $\begin{array}{c}\text { Portfolio } \\
\mathbf{2}\end{array}$ & $\begin{array}{c}\text { Portfolio } \\
\mathbf{3}\end{array}$ & $\begin{array}{c}\text { Portfolio } \\
\mathbf{4}\end{array}$ & $\begin{array}{c}\text { Portfolio } \\
\mathbf{5} \\
\text { (stocks } \\
\text { with the } \\
\text { least } \\
\text { smooth } \\
\text { past } \\
\text { earnings) }\end{array}$ \\
\hline $\begin{array}{c}\text { Average } \\
\text { return rate* }\end{array}$ & $16.0 \%$ & $15.4 \%$ & $18.1 \%$ & $20.3 \%$ & $19.7 \%$ \\
\hline $\begin{array}{c}\text { Beta } \\
\text { coefficient** }\end{array}$ & 1.53 & 1.49 & 1.53 & 1.53 & 1.54 \\
\hline $\begin{array}{c}\text { Standard } \\
\text { deviation } \\
\text { of returns*** }\end{array}$ & $69.7 \%$ & $67.8 \%$ & $65.0 \%$ & $68.5 \%$ & $68.1 \%$ \\
\hline $\begin{array}{c}\text { Coefficient of } \\
\text { variation } \\
\text { of returns**** }\end{array}$ & $221.8 \%$ & $222.2 \%$ & $196.5 \%$ & $190.5 \%$ & $196.9 \%$ \\
\hline
\end{tabular}

Source: Money.pl; Notoria Serwis; author's calculations.

Note: * geometric average of the annual nominal returns in a ten-year period between the end of February 2003 and the end of February 2013; ** slope parameter of the regression of the annual returns of individual portfolios against the annual returns of the Warsaw Stock Exchange WIG Index; *** standard deviation of the annual nominal returns in a ten-year period between the end of February 2003 and the end of February 2013 ; **** standard deviation of the annual returns / arithmetic average of the annual returns.

Thus, it seems that if investors expect the positive risk-return relationship within the universe of stocks differing by past earnings smoothness, it is rather the perceived risk (and not the actual one) which 
is reflected in relatively high valuation multiples and below-average returns of companies with smooth historical earnings. The alternative explanation (other than the expected risk premium) for the sub-par returns of those stocks is the investors' over-extrapolation of their historical earnings trends. According to the behavioural economics, if the investors get trapped into the "anchoring bias", they put too much weight on the recent observations in predicting the future. As a result, they may overextrapolate both past earnings smoothness as well as historical growth rate of earnings. If this is the case, particularly in terms of stocks with smoothly growing earnings, than their below-average long-term returns may stem from the future "negative earnings surprises". To test this, we compared the behaviour of the next-year earnings within the investigated five portfolios.

\subsection{Relationship between past earnings smoothness and next-year earnings}

Table 6 presents the median errors of the next-year earnings extrapolated from their linear trends in the last five years as well as the median earnings growth rates for the following (sixth) year. For comparison, we also provide the median earnings growth rate in the last year (before the forecast is made) and the test statistics for the differences between the next-year and the last-year averaged growth rates. Table 7 and Table 8 contain the absolute values of the Wilcoxon Rank-Sum test statistics for the inter-portfolio differences in the respective medians.

The companies with the smoothest past earnings tend to report the "negative earnings surprises" in the following year. According to our data, within Portfolio 1 the earnings reported for the next year miss the extrapolated earnings by more than $9 \%$, on average. This lies in a sharp contrast to other portfolios, where the actual next-year earnings tend to "beat" the extrapolated ones. According to Table 7, in case of the forecast errors the differences between the median for Portfolio 1 and the medians for the other portfolios are statistically significant at $5 \%$ significance level. In contrast, the differences between the other medians (that is between the medians for all portfolios except for Portfolio 1) are statistically insignificant. This suggests that the high smoothness of past five-year earnings increases the probability of the next-year "negative earnings surprise". 
Welc, J.: Impact of Earnings Smoothness on Stock Prices, Stock Returns and Future Earnings Changes - the Polish Experience.

Tab. 6. The next-year and the last-year earnings

\begin{tabular}{|c|c|c|c|c|c|}
\hline $\begin{array}{c}\text { Within- } \\
\text { portfolios } \\
\text { medians of: }\end{array}$ & $\begin{array}{c}\text { Portfolio } 1 \\
\text { (stocks } \\
\text { with the } \\
\text { smoothest } \\
\text { past } \\
\text { earnings) }\end{array}$ & $\begin{array}{c}\text { Portfolio } \\
2\end{array}$ & $\begin{array}{c}\text { Portfolio } \\
\mathbf{3}\end{array}$ & $\begin{array}{c}\text { Portfolio } \\
4\end{array}$ & $\begin{array}{c}\text { Portfolio } 5 \\
\text { (stocks } \\
\text { with the } \\
\text { least } \\
\text { smooth } \\
\text { past } \\
\text { earnings) }\end{array}$ \\
\hline $\begin{array}{l}\text { 1) Next-year } \\
\text { earnings } \\
\text { forecast } \\
\text { errors* }\end{array}$ & $9.1 \%$ & $-7.2 \%$ & $-9.6 \%$ & $-9.6 \%$ & $-30.7 \%$ \\
\hline $\begin{array}{l}\text { 2) Next-year } \\
\text { earnings } \\
\text { growth rate** }\end{array}$ & $4.0 \%$ & $23.6 \%$ & $13.9 \%$ & $2.4 \%$ & $23.4 \%$ \\
\hline $\begin{array}{l}\text { 3) Last-year } \\
\text { earnings } \\
\text { growth rate** }\end{array}$ & $22.8 \%$ & $17.6 \%$ & $20.4 \%$ & $9.2 \%$ & $0.0 \%$ \\
\hline $\begin{array}{l}\text { 4) Absolute } \\
\text { value of } \\
\text { Wilcoxon } \\
\text { Rank-Sum } \\
\text { test } \\
\text { statistic*** }\end{array}$ & 2.92 & 0.44 & 1.61 & 1.93 & 1.64 \\
\hline
\end{tabular}

Source: Money.pl; Notoria Serwis; author's calculations.

Note: * with errors of individual forecasts computed in accordance to formula (2); ** with individual growth rates computed in accordance to formula (3); *** value above 1.96 means that the difference between the two medians is statistically significant at $5 \%$ significance level

The stocks included in Portfolio 1 are also featured by the fastest reported last-year growth $(22.9 \% \mathrm{y} / \mathrm{y}$, on average $)$ and much slower nextyear growth $(4 \% \mathrm{y} / \mathrm{y}$, on average). According to the last row of Table 6 , this is the only portfolio in which case the difference between the averaged last-year growth and the averaged next-year growth is statistically significant at $5 \%$ significance level. Although, according to Table 8 , the median next-year earnings growth rate within Portfolio 1 differs significantly only from the respective median computed for 
Portfolio 5, the extent of the next-year earnings growth slowdown seems to constitute the another evidence that high smoothness of past five-year earnings tends to be followed by disappointing next-year earnings.

Tab. 7. The absolute values of the Wilcoxon Rank-Sum test statistics* for the inter-portfolio differences of medians of next-year earnings forecast errors

\begin{tabular}{|l|c|c|c|c|c|}
\hline & Portfolio & Portfolio & Portfolio & Portfolio & Portfolio \\
\hline Portfolio 1 & - & 2.39 & 2.90 & 2.65 & 3.70 \\
\hline Portfolio 2 & & - & 0.51 & 0.44 & 1.22 \\
\hline Portfolio 3 & & & - & 0.14 & 0.63 \\
\hline Portfolio 4 & & & & - & 0.81 \\
\hline Portfolio 5 & & & & & - \\
\hline
\end{tabular}

Source: Money.pl; Notoria Serwis; author's calculations.

Note: * value above 1.96 means that the difference between the two medians is statistically significant at $5 \%$ significance level

Tab. 8. The absolute values of the Wilcoxon Rank-Sum test statistics* for the inter-portfolio differences of medians of next-year earnings growth rates

\begin{tabular}{|l|c|c|c|c|c|}
\hline & Portfolio & Portfolio & Portfolio & Portfolio & Portfolio \\
\hline Portfolio 1 & - & 1.77 & 0.79 & 0.59 & 2.15 \\
\hline Portfolio 2 & & - & 0.86 & 1.95 & 0.89 \\
\hline Portfolio 3 & & & - & 1.07 & 1.68 \\
\hline Portfolio 4 & & & & - & 2.55 \\
\hline Portfolio 5 & & & & & - \\
\hline
\end{tabular}

Source: Money.pl; Notoria Serwis; author's calculations.

Note: * value above 1.96 means that the difference between the two medians is statistically significant at $5 \%$ significance level 
Welc, J.: Impact of Earnings Smoothness on Stock Prices, Stock Returns and Future Earnings Changes - the Polish Experience.

\section{Conclusions}

Capital markets appreciate stability. Companies that report smooth earnings are valued relatively higher, on average, than firms with noisier patterns of earnings. Valuation multiples of stocks with smooth past earnings contain empirically observable valuation premiums, which reflect market beliefs in either their relatively low future investment risks or relatively fast future earnings growth (or both). On the other hand, stocks with relatively erratic past earnings are quoted with empirically observable valuation discounts. Our empirical investigation confirmed the existence of the statistically significant positive relationship between past earnings smoothness and relative stock prices, on the basis of data from the Polish stock market from 1998 - 2012 period.

Our research also found that stocks with relatively smooth historical earnings bring sub-par long-term stock returns while stocks with relatively erratic earnings generate above-average long-term returns. Furthermore, the below-average returns of stocks with smooth past earnings are not compensated by their relatively low investment risks (as suggested by the theory of the positive risk-return relationship). Beta coefficients and standard deviations of returns do not show any discernible differences between the portfolios varying in terms of past earnings smoothness. The only visible differences are seen for coefficients of variation of stock returns, which are however somewhat smaller for the portfolios with relatively erratic earnings. Thus, if investors treat past earnings smoothness as a proxy for the expected investment risk, then stocks with smooth patterns of historical earnings, with their observable valuation premiums, tend to be overvalued (because past earnings smoothness does not translate into future relative variability of stock returns).

Moreover, the companies with smooth past earnings tend to report the "negative earnings surprises" in the following year. Their next-year reported earnings tend to miss the extrapolated ones, opposite to the portfolios composed of stocks with more noisy earnings. Stocks with smooth past earnings are also featured by the deep and statistically significant slowdown of their earnings growth rates in the following year.

To sum up, stocks with smooth past earnings offer neither the relatively low future investment risks nor the relatively fast future earnings growth. This, in turn, means that their empirically observed valuation premiums imply stock overvaluation. Our findings suggest that such valuation premiums are undeserved and reflect the investors' over- 
extrapolation of the past earnings patterns (which brings sub-par future stock returns).

Nevertheless, our study has some relevant limitations. First of all, the period covered by the research is pretty short and covers only several stock market cycles. Moreover, during the time under investigation the Polish economy did not experience any single year of a recession. This means that our results can be somewhat biased. It's important qualification because in the case of a recession (particularly the deep and unforeseen one) the higher number of companies could go bankrupt, which could change our findings. This limitation justifies the inclusion of the longer time-series of data. Regrettably, the extension of our sample further into the past is not viable, owing to the small number of then listed companies. Also, the double-digit inflation environment in which the Polish economy functioned in the 1990s could probably distort the results. Our findings might be also distorted by the "survivorship bias". During the years under investigation some companies listed on the Warsaw Stock Exchange did go bankrupt and these bankruptcies were probably preceded by a boosted variability of earnings. In many cases the noisy behaviour of earnings before bankruptcy would imply the inclusion of those companies into the erratic-earnings portfolios. Unfortunately, these cases cannot be fully allowed for in the study because of the deficiencies of the available databases. Finally, our findings may be influenced by some other factors, not allowed for in our analysis, which can be correlated with both valuation multiples as well as with the smoothness of past earnings (such as capitalization of companies or transaction costs). In the further research we would like to refine our findings, as far as possible, by allowing for these shortcomings.

\section{References}

Aflatooni, A. - Nikbakht, Z. (2010): Income Smoothing, Real Earnings Management and Long-Run Stock Returns. Business Intelligence Journal, 2010, vol. 3, no. 1, pp. 55-73.

Allayannis, G. - Simko, P. J. (2009): Earnings Smoothing, Analyst Following, and Firm Value. <http://ssrn.com/abstract=1361228>.

Amiram, D. - Owens, E. (2010): Earnings Smoothness and Cost of Debt. University of North Carolina Working Papers, 2010. 
Welc, J.: Impact of Earnings Smoothness on Stock Prices, Stock Returns and Future Earnings Changes - the Polish Experience.

Badrinath, S. G. - Gay, G. D., Kale, J. R. (1989): Patterns of Institutional Investment, Prudence, and the Managerial 'Safety-Net' Hypothesis. Journal of Risk and Insurance, 1989, vol. 56, no: 4, pp. 605-629.

Barefield, R. - Comiskey, E. (1972): The Smoothing Hypothesis: An Alternative Test. The Accounting Review, 1972, vol. 47, no. 2, pp. 291298.

Barnea, A. - Ronen, J., Sadan, S. (1975): The Implementation of Accounting Objectives - An Application to Extraordinary Items. The Accounting Review, 1975, vol. 50, no. 1, pp. 58-68.

Barnes, R. (2001): Earnings Volatility and Market Valuation: An Empirical Investigation. London Business School Working Paper, no. ACCT019.

Barth, M. E. - Elliott, J. A. - Finn, M. W. (1999): Market Rewards Associated with Patterns of Increasing Earnings. Journal of Accounting Research, 1999, vol. 37, no. 2, pp. 387-413.

Beattie, V. - Brown, S. - Ewers, D. - John, B. - Manson, S., Thomas, D. - Turner, M. (1994): Extraordinary Items and Income Smoothing: A Positive Accounting Approach. Journal of Business Finance \& Accounting, 1994, vol. 21, no. 6, pp. 791-811.

Beaver, W. H. - Kettler, P. - Scholes, M. (1970): The Association Between Market Determined and Accounting Determined Risk Measures. The Accounting Review, 1970, vol. 45, no. 4, pp. 654-682.

Beidleman, C. (1973): Income Smoothing: The Role of Management. The Accounting Review, 1973, vol. 48, no. 4, pp. 653-667.

Bhattacharya, U. - Daouk, H. - Welker, M. (2003): The World Price of Earnings Opacity. The Accounting Review, 2003, vol. 78, no. 3, pp. 641678.

Billings, B. (1999): Is Earnings Variability Related to Future Stock Returns? Florida State University Working Papers.

Booth, G. G. - Kallunki, J. P. - Martinkainen, T. (1996): PostAnnouncement Drift and Income Smoothing: Finnish Evidence. Journal of Business Finance and Accounting, 1996, vol. 23, no. 8, pp. 1197-1212.

Bowman, R. (1979): The Theoretical Relationship Between Systematic Risk and Financial (Accounting) Variables. Journal of Finance, 1979, vol. 34, no. 3, pp. 617-630. 
Brown, L. D. (1996): Analyst Forecasting Errors and Their Implications for Security Analysis: An Alternative Perspective. Financial Analyst Journal, 1996, vol. 52, no. 1, pp. 40-47.

Carlson, S. J. - Bathala, C. T. (1997): Ownership Differences and Firms' Income Smoothing Behavior. Journal of Business Finance and Accounting, 1997, vol. 24, no. 2, pp. 179-196.

Chaney, P. K. - Lewis, C. M. (1995): Earnings Management and Firm Valuation under Asymmetric Information. Journal of Corporate Finance, 1995, vol. 1, no. 3-4, pp. 319-345.

Charemza, W. W. - Deadman, F. D. (1997): Nowa ekonometria. Warsaw, PWE, 1997.

Chen, L. C. (2009): Income Smoothing, Information Uncertainty, Stock Returns, and Cost of Equity. A Dissertation Submitted to the Faculty of the Committee on Business Administration In Partial Fulfillment of the Requirements for the Degree of Doctor of Philosophy with Major in Management in the Graduate College. The University of Arizona, 2009.

Cornell, B. (1999): The Equity Risk Premium. The Long-Run Future of the Stock Market. New York, John Wiley \& Sons, 1999.

Dascher, P. - Malcolm, R. (1970): A Note on Income Smoothing in the Chemical Industry. Journal of Accounting Research, 1970, Autumn, pp. 253-260.

Dey, A. (2004): Income Smoothing and Sophisticated Investor Preferences. Kellog School of Management. SSRN, $<$ http://ssrn.com/abstract=571541>.

Dichev, I. - Tang, V. W. (2009): Earnings Volatility and Earnings Predictability. Journal of Accounting and Economics, 1009, vol. 47, no. 1-2, pp. 160-181.

Dreman, D. (1998): Contrarian Investment Strategies. The Next Generations: Beat the Market by Going Against the Crowd. New York, Simon \& Shuster, 1998.

Easley, D. - O'Hara, M. (2004): Information and the Cost of Capital. Journal of Finance, 2004, vol. 59, no. 4, pp. 1553-1583.

Evans, M. (2003): Practical Business Forecasting. Oxford, Blackwell Publishing, 2003. 
Welc, J.: Impact of Earnings Smoothness on Stock Prices, Stock Returns and Future Earnings Changes - the Polish Experience.

Fernandez, P. (2002): Valuation Using Multiples. How Do Analysts Reach Their Conclusions? IESE Business School Research Papers No. 450, 2002.

Francis, J. - LaFond, R. - Olsson, P. M. - Schipper, K. (2004): Costs of Equity and Earnings Attributes. The Accounting Review, 2004, vol. 79, no. 4, pp. 967-1010.

Fudenberg, D. - Tirole, J. (1995): A Theory of Income and Dividend Smoothing Based on Incumbency Rents. Journal of Political Economy, 1995, vol. 103, no. 1, pp. 75-93.

Gebhardt, W. R. - Lee, C. M. C., Swaminathan, B. (1999): Toward an Ex Ante Cost-of-Capital. Parker Center for Investment Research Working Paper Series 98-6, 1999.

Gode, D. - Mohanram, P. (2001): What Affects the Implied Cost of Equity Capital?. Stern School of Business Working Papers No. 2451/27478, 2001.

Goel, A. M. - Thakor, A. V. (2000): Why Do Firms Smooth Earnings? The Journal of Business, 2000, vol. 76, no. 1, pp. 151-192.

Gordon, M. J. (1964): Postulates, Principles and Research in Accounting. The Accounting Review, 1964, vol. 39, no. 2, pp. 251-263.

Graham, J. R. - Harvey, C. R. - Rajgopal, S. (2005): The Economic Implications of Corporate Financial Reporting. Journal of Accounting and Economics, 2005, vol. 40, no. 1-3, pp. 3-73.

Gu, Z. - Zhao, J. Y. (2006): Information Precision and the Cost of Debt. Carnegie Mellon University Working Paper, 2006.

He, W. - Sidhu, B. K. - Tan, H. C. (2010): Income Smoothing and Properties of Analyst Information Environment. Paper presented at AAA Annual Meeting and CTLA, San Francisco, 2-4 August 2010.

Hepworth, S. R. (1953): Smoothing Periodic Income. The Accounting Review, 1953, vol. 28, no. 1, pp. 32-39.

Hunt, A. - Moyer, S. E. - Shevlin, T. (2000): Earnings Volatility, Earnings Management, and Equity Value. University of Washington Working Paper, 2000. 
Jiang, G. - Lee, C. M. C. - Zhang, Y. (2005): Information Uncertainty and Expected Returns. Review of Accounting Studies, 2005, vol. 10, no. 2-3, pp. 185-221.

Jones, Ch. P. (1998): Investments. Analysis and Management. New York, John Wiley \& Sons, 1998.

Jung, B. - Soderstrom, N. - Yang, S. (2012): Earnings Smoothing Activities of Firms to Manage Credit Ratings. Contemporary Accounting Research, 2012, vol. 30, no. 2, pp. 1-49.

Lakonishok, J. - Shleifer, A. - Vishny, R. W. (1994): Contrarian Investment, Extrapolation, and Risk. The Journal of Finance, vol. 49, no. 5, pp. 1541-1578.

Leuz, C. - Nanda, D. - Wysocki, P. D. (2003): Earnings Management and Investor Protection: An International Comparison. Journal of Financial Economics, 2003, vol. 69, no. 3, pp. 505-527.

Lev, B. - Kunitsky, S. (1974): On the Association Between Smoothing Measures and the Risk of Common Stocks. The Accounting Review, 1974, vol. 49, no. 2, pp. 259-270.

Li, S. - Richie, N. (2009): Income Smoothing and the Cost of Debt. Wilfrid Laurier University Working Paper, 2009.

Mäkelä, M. (2012): The Effect of Smooth Performance in Firm Value. European Evidence. Aalto University School of Economics Finance Master's Thesis, 2012.

Malkiel, B. G. (2007): A Random Walk Down Wall Street. The TimeTested Strategy for Successful Investing. New York, W.W. Norton \& Company, 2007.

Markarian, G. - Gill-de-Albornoz, B. (2010): Income Smoothing and Indiosyncratic Volatility. Paper presented at AAA 2010 Financial Accounting and Reporting Section (FARS), November 2010.

McInnis, J. (2010): Earnings Smoothness, Average Returns, and Implied Cost of Equity Capital. The Accounting Review, 2010, vol. 85, no. 1, pp. 315-341.

Michelson, S. E. - Wagner, J. J. - Wootton, C. W. (2000): The Relationship Between the Smoothing of Reported Income and RiskAdjusted Return. Journal of Economics and Finance, 2000, vol. 24, no. 2, pp. 141-159. 
Welc, J.: Impact of Earnings Smoothness on Stock Prices, Stock Returns and Future Earnings Changes - the Polish Experience.

Myers, J. - Myers, L. - Skinner, D. (2007): Earnings Momentum and Earnings Management. Journal of Accounting, Auditing \& Finance, 2007, vol. 22, no. 2, pp. 249-284.

Nelson, M. W. - Elliott, J. A. - Tarpley, R. A. (2002): Evidence from Auditors about Managers' and Auditors' Earnings Management Decisions. The Accounting Review, 2002, vol. 77, no. 1, pp. 175-202.

O'Brien, P. C. (1988): Analysts' Forecasts as Earnings Expectations. Journal of Accounting and Economics, 1988, vol. 10, no. 1, pp. 53-83.

Previts, G. J. - Bricker, R. J. - Robinson, T. R. - Young, S. J. (1994): A Content Analysis of Sell-Side Financial Analyst Company Reports. Accounting Horizons, 1994, vol. 8, no. 2, pp. 55-70.

Ronen, J. - Sadan, S. (1981): Smoothing Income Numbers. Objectives, Means and Implications. Addison-Wesley Publishing Company.

Rountree, B. - Weston, J. - Allayannis, G. (2008): Do Investors Value Smooth Performance? Journal of Financial Economics, 2008, vol. 90, no. 3, pp. 237-251.

Rosenberg, B. - McKibben, W. (1973): The Prediction of Systematic and Specific Risk in Common Stocks. Journal of Financial and Quantitative Analysis, 1973, vol. 8, no. 2, pp. 317-333.

Rothovius, T. (2008): Earnings and Analysts' Forecasts. The American Finance Association Meeting Presentation, University of Oulu.

Singer, Z. (2007): Discretionary Financial Reporting: Items Manipulated by IPO Firms, and Investors' Increased Awareness. University of California in Berkeley Dissertation, 2007.

Skinner, D. J. - Sloan, R. G. (1999): Earnings Surprises, Growth Expectations, and Stock Returns, or Don't Let an Earnings Torpedo Sink Your Portfolio. SSRN, <http://ssrn.com/abstract=172060>.

Suda, I. - Hanaeda, H. (2008): Nihon kigyo no zaimu hokoku: survey tyosa ni yoru bunseki (Corporate financial reporting strategy: survey evidence from Japanese firms). Securities Analysts Journal, 2008, vol. 46, no. 5, pp. 51-69.

Takasu, Y. - Nakano, M. (2012): What Do Smoothed Earnings Tell Us About the Future?. The Japanese Accounting Review, 2012, vol. 2, no. December, pp. 1-32. 
Trueman, B. - Titman, S. (1988): An Explanation for Accounting Income Smoothing. Journal of Accounting Research, 1988, vol. 26, no. 3, pp. 127139.

Verdi, R. (2006): Information Environment and the Cost of Equity Capital. Massachusetts Institute of Technology Working Paper, July 7, 2005.

Wang, Z. - Williams, T.H. (1994): Accounting Income Smoothing and Stockholder Wealth. Journal of Applied Business Research, 1994, vol. 10, no. 3, pp. 96-104.

Welc, J. (2011): Do Fundamentally-Adjusted Valuation Multiples Improve Valuation Accuracy? The Case of the Polish Stock Market. Accounting \& Taxation, vol. 3, no. 1, pp. 57-70. 


\title{
Impact of Earnings Smoothness on Stock Prices, Stock Returns and Future Earnings Changes - the Polish Experience
}

\begin{abstract}
Capital markets appreciate stability. It means that companies reporting smooth earnings patterns tend to be priced relatively high. However, the empirical issue is whether such valuation premiums for earnings smoothness are justified. We examine the relationships between past fiveyear earnings smoothness and relative stock prices of companies listed on the Warsaw Stock Exchange. The empirical investigation confirmed that on the Polish market the smooth historical earnings are rewarded with valuation premiums and the erratic earnings are penalized with valuation discounts. However, stocks with smooth past earnings tend to bring subpar future stock returns while stocks with relatively erratic earnings seem to generate above-average returns. Furthermore, the scope of past earnings smoothness does not show any discernible relationships to realized investment risk measures. Finally, companies with smooth earnings tend to report "negative earnings surprises" and relatively slow earnings growth rates in the following year. All in all, our research suggests that there is not any empirically observable justification for the valuation premiums observed in the case of stocks with smooth past earnings because such smoothness translate neither into relatively low future investment risks nor relatively fast future earnings growth.
\end{abstract}

Key words: Stock valuation; Stock returns; Earnings smoothness; Valuation multiples.

JEL Classification: G11, C21 